Г. С. Тартинська ${ }^{1}$, І. О. Журавель ${ }^{1}$, В. С. Кисличенко ${ }^{1}$, В. В. Гуцол르, А. В. Мартинов ${ }^{3}$ НАЦІОНАЛЬНИЙ ФАРМАЦЕВТИЧНИЙ УНІВЕРСИТЕТ ${ }^{1}$, ХАРКІВ ВІННИЦЬКИЙ НАЦІОНАЛЬНИЙ МЕДИЧНИЙ УНІВЕРСИТЕТ ІМЕНІ М. І. ПИРОГОВА ІНСТИТУТ МІКРОБІОЛОГІЇ ТА ІМУНОЛОГІЇ ІМЕНІ І. І. МЕЧНИКОВАЗ

\title{
ДОСЛІДЖЕННЯ АМІНОКИСЛОТНОГО СКЛАДУ ТРАВИ ЯЧМЕНЮ ЗВИЧАЙНОГО І ЖИТА ПОСІВНОГО
}

Вступ. Амінокислоти мають багатовекторну фрармакологічну активність, тому актуальними $\epsilon$ пошук нових джерел амінокислот і дослідження їх складу в лікарських рослинах.

Мета дослідження - вивчити якісний склад амінокислот, визначити їх вміст у траві ячменю звичайного і жита посівного.

Методи дослідження. Ідентифікацію та визначення кількісного вмісту амінокислот проводили методом іонообмінної рідинно-колонкової хроматограффії.

Результати й обговорення. У досліджуваній сировині якісний склад та кількісний вміст домінуючих амінокислот були майже ідентичними. Загальний вміст амінокислот у траві ячменю звичайного становив 5,988 мг/100 мг, у траві жита посівного - 4,359 мг/100 мг. У траві ячменю звичайного серед замінних амінокислот у значній кількості накопичувались аспарагінова і глутамінова кислоти та пролін (25,63 \%, 16,25 \%, 12,91 \% від суми амінокислот відповідно), серед незамінних - лізин (5,00 \% від суми амінокислот). У траві жита посівного за вмістом переважали замінні амінокислоти: глутамінова кислота, пролін, аспарагінова кислота (17,88 \%, 10,99%, 10,63 \% від суми амінокислот відповідно), серед незамінних - лейцин, лізин, френілаланін (7,14 \%, 6,13 \%, 4,61 \% від суми амінокислот відповідно). Серед незамінних амінокислот у мінорній кількості у траві жита посівного та ячменю звичайного містився метіонін (1,40 і 0,88 \% від суми амінокислот відповідно).

Висновки. Уперше вивчено якісний склад та визначено кількісний вміст амінокислот у траві ячменю звичайного і жита посівного. Встановлено вміст 18 амінокислот, з яких 7 належать до незамінних, 8 - до замінних, 3 - до напівзамінних. Серед ідентифрікованих амінокислот домінували аспарагінова і глутамінова кислоти, пролін, у значній кількості містилися лейцин, лізин і френілаланін. Одержані результати проведених досліджень можуть бути використані при розробці нових рослинних лікарських засобів на основі ячменю звичайного і жита посівного.

КЛЮЧОВІ СЛОВА: ячмінь звичайний; жито посівне; амінокислоти; іонообмінна рідинно-колонкова хроматографія.

ВСТУП. Амінокислоти є найбільш цінними структурними елементами рослин та важливою складовою частиною організму людини.

Амінокислоти можна поділити на незамінні (есенціальні), замінні та напівзамінні. Слід зазначити, що есенціальні амінокислоти не можуть синтезуватись організмом, а тому при їх відсутності в їжі він починає використовувати резервні запаси амінокислот.

Незамінні амінокислоти становлять найбільший інтерес для організму людини, до них належать: валін, лейцин, ізолейцин, лізин, метіонін, треонін, триптофран і френілаланін. Відсутність або недостатність цих амінокислот викликає негативний баланс нітрогену, призводить до

(C) Г. С. Тартинська, І. О. Журавель, В. С. Кисличенко, В. В. Гуцол, А. В. Мартинов, 2021. затримки росту і розвитку організму, зменшення маси тіла, порушення обміну речовин.

Лейцин прискорює відновлення м'язової тканини, кісток і шкіри. Лізин необхідний для засвоєння кальцію, нормалізації серцевого тонусу, проявляє гіпохолестеринемічну та імуностимулювальну дію, підсилює резистентність організму і сприяє продукуванню колагену. Фенілаланін регулює відчуття ситості, посилює роботу щитоподібної залози, покращує пам'ять і концентрацію уваги, сприяє циркуляції крові, бере участь в утворенні інсуліну. Валін відповідає за підтримання обміну нітрогену в організмі. Ізолейцин необхідний для регулювання рівня цукру в крові.

Замінні амінокислоти мають не менш важливе значення, ніж есенціальні. У разі їх недо- 
статності вони можуть бути синтезовані в процесі метаболізму в організмі з інших амінокислот або з небілкових компонентів. До замінних кислот належать: аспарагінова, глутамінова кислоти, у-аміномасляна кислота, серин, гліцин, аланін, пролін, цистин.

Глутамінова кислота стимулює пам'ять і мислення, бере участь у синтезі протеїну. Аспарагінова кислота входить до складу нуклеотидів і нуклеїнових кислот. Пролін відповідає за зміцнення серцевого м'яза. Аланін $€$ енергетичним джерелом для нервової системи та головного мозку, відповідає за зміцнення імунної системи. Гліцин регулює метаболічні процеси в центральній нервовій системі [1-6].

Слід зауважити, що амінокислоти мають багатовекторну фрармакологічну активність, їх можна використовувати як у комплексі, так і окремо для профрілактики та лікування багатьох захворювань. Тому важливим та актуальним є дослідження амінокислот у харчових рослинах.

Для подальшого фрармакогностичного дослідження ми вивчали якісний склад та кількісний вміст амінокислот у траві ячменю звичайного (Hordeum vulgare L.) і жита посівного (Secale cereale L.). Одержані результати можна буде враховувати при розробці нових лікарських засобів рослинного походження та дієтичних добавок на їх основі $[7,8]$.

Мета дослідження - вивчити якісний склад амінокислот, визначити їх вміст у траві ячменю звичайного і жита посівного.

МЕТОДИ ДОСЛІДЖЕННЯ. Об'єКТом дОслідження була трава ячменю звичайного (сорт Шедевр) і жита посівного (сорт Хамарка), заготовлена в період колосіння. Ці зразки заготовлено у 2019-2020 рр. на полях Інституту рослинництва імені В. Я. Юр'єва Національної академії аграрних наук України.

Ідентифікацію та визначення кількісного вмісту амінокислот у досліджуваних зразках ячменю і жита проводили методом іонообмінної рідинно-колонкової хроматографії на автоматичному аналізаторі амінокислот АААТ-339M ("Мікротехн", Чехія), обладнаному реєструвальним фротоелементом.

Для визначення суми амінокислот наважку повітряно-сухої подрібненої сировини масою близько 100 мг поміщали на дно пробірки з вогнетривкого скла. У пробірку додавали 0,5 мл води очищеної та 0,5 мл концентрованої хлористоводневої кислоти, після чого охолоджували за допомогою суміші сухого льоду з диметилкетоном. Після охолодження для запобігання окисненню амінокислот вакуумним насосом із пробірки викачували повітря. Гідроліз протеїнів проводили хлористоводневою кислотою протягом доби в термостаті з постійною температурою $+106{ }^{\circ} \mathrm{C}$. Після закінчення гідролізу пробірку охолоджували до кімнатної температури та розкривали.

Вміст пробірки кількісно переносили у скляний бюкс і поміщали у вакуумний ексикатор над гранульованим гідроксидом натрію та видаляли повітря вакуумним насосом. Зразки висушували, після чого в бюкси додавали 3-4 мл деіонізованої води і повторювали процедуру висушування. Підготовлені зразки розчиняли в 0,3 Н літій-цитратному бусрері (pH 2,2) і наносили на іонообмінну колонку аналізатора амінокислот (Ostion LGANB), заповнену катіонітом.

Амінокислоти в елюатах реєстрували методом детекції нінгідрином. На виході з колонки до елюату мікронасосом безперервно подавали нінгідриновий реактив у визначеному співвідношенні з елюатом. Цю суміш по капілярній трубці направляли в нагрітий до температури +95$98^{\circ} \mathrm{C}$ реактор, потім - у кювету. Нінгідрин, взаємодіючи з амінокислотою по аміногрупі, утворює сполуку з максимумом поглинання при 560 нм (окрім сполук з проліном і оксипроліном, які мають максимум поглинання при 440 нм). Інтенсивність утвореного забарвлення вимірювали за допомогою фотоколориметрування. Сигнали фротоелемента підсилювали і реєстрували самописним потенціометром у вигляді хроматограми.

Кількість мікромолей амінокислоти у досліджуваному зразку визначали за відношенням площі піка амінокислоти в досліджуваному зразку до площі піка цієї ж самої амінокислоти в розчині стандартної суміші амінокислот, що відповідає одному мікромолю кількості кожної амінокислоти. Кількісний вміст амінокислоти в міліграмах розраховували, помноживши кількість мікромолей на молекулярну масу амінокислоти [2, 4, 9-12]:

$$
\mathrm{X}=\mathrm{Son} \cdot \mathrm{KS} \cdot \mathrm{MB} / \mathrm{ScT} \text {, }
$$

де Son - площа піка амінокислоти в зразку; $\mathrm{Sct}$ - площа піка амінокислоти в стандартній суміші;

KS - коефріцієнт, що враховує масу і розведення зразка;

Мв - молекулярна маса амінокислоти.

Якісний склад амінокислот визначали, порівнюючи хроматограми стандартної і досліджуваної сумішей.

РЕЗУЛЬТАТИЙ ОБГОВОРЕННЯ. РЕЗУЛЬТаТИ дослідження амінокислотного складу трави жита посівного та ячменю звичайного наведено в таблиці. 
Таблиця - Вміст амінокислот у траві жита посівного (сорт Хамарка) та ячменю звичайного (сорт Шедевр)

\begin{tabular}{|c|c|c|c|c|}
\hline \multirow{3}{*}{ Амінокислота } & \multicolumn{4}{|c|}{ Вміст амінокислот у траві } \\
\hline & \multicolumn{2}{|c|}{ жита посівного } & \multicolumn{2}{|c|}{ ячменю звичайного } \\
\hline & $\begin{array}{l}\text { мг/100 мг } \\
\text { сировини }\end{array}$ & $\begin{array}{c}\text { \% від загальної } \\
\text { суми амінокислот }\end{array}$ & $\begin{array}{l}\text { мг/100 мг } \\
\text { сировини }\end{array}$ & $\begin{array}{c}\text { \% від загальної } \\
\text { суми амінокислот }\end{array}$ \\
\hline Лізин ${ }^{\star}$ & 0,267 & 6,13 & 0,299 & 5,00 \\
\hline Фенілаланін* & 0,201 & 4,61 & 0,199 & 3,32 \\
\hline Валін* & 0,129 & 2,96 & 0,150 & 2,51 \\
\hline Лейцин* & 0,311 & 7,14 & 0,202 & 3,37 \\
\hline Ізолейцин ${ }^{*}$ & 0,109 & 2,50 & 0,098 & 1,63 \\
\hline Метіонін ${ }^{\star}$ & 0,061 & 1,40 & 0,053 & 0,88 \\
\hline Треонін ${ }^{\star \star}$ & 0,180 & 4,13 & 0,158 & 2,64 \\
\hline Цистин & 0,093 & 2,14 & 0,111 & 1,86 \\
\hline Гліцин & 0,249 & 5,71 & 0,223 & 3,72 \\
\hline Аланін & 0,285 & 6,54 & 0,306 & 5,12 \\
\hline Аспарагінова кислота & 0,463 & 10,63 & 1,535 & 25,63 \\
\hline Глутамінова кислота & 0,780 & 17,88 & 0,973 & 16,25 \\
\hline у-аміномасляна кислота (ГАМК) & 0,039 & 0,89 & 0,104 & 1,73 \\
\hline Аргінін ${ }^{\star \star}$ & 0,254 & 5,82 & 0,227 & 3,80 \\
\hline Серин & 0,183 & 4,20 & 0,295 & 4,93 \\
\hline Тирозин & 0,131 & 3,00 & 0,176 & 2,93 \\
\hline Гістидин ${ }^{\star \star}$ & 0,145 & 3,33 & 0,106 & 1,77 \\
\hline Пролін & 0,479 & 10,99 & 0,773 & 12,91 \\
\hline Сума незамінних амінокислот & 1,258 & 28,87 & 1,159 & 19,35 \\
\hline Сума замінних амінокислот & 3,101 & 71,13 & 4,829 & 80,65 \\
\hline Сума амінокислот & 4,359 & 100,00 & 5,988 & 100,00 \\
\hline
\end{tabular}

Примітка. * - незамінні амінокислоти; *夫 - напівзамінні амінокислоти.

У результаті дослідження у траві ячменю звичайного і жита посівного ідентифіковано по 18 амінокислот: 7 незамінних (лізин, треонін, валін, метіонін, френілаланін, ізолейцин, лейцин), 8 замінних (аспарагінова, глутамінова, y-аміномасляна кислоти, серин, гліцин, аланін, пролін, цистин), 3 напівзамінних (аргінін, тирозин, гістидин). Також у ході порівняльного аналізу з'ясовано, що якісний склад та кількісний вміст амінокислот були майже ідентичними у досліджуваній сировині. Загальний вміст амінокислот у траві ячменю звичайного становив 5,988 мг/100 мг, у траві жита посівного 4,359 мг/100 мг.

Ідентифріковані амінокислоти можна розташувати в такій послідовності за зменшенням їх вмісту в досліджуваних зразках:

- ячмінь звичайний: аспарагінова кислота > глутамінова кислота > пролін > аланін > лізин > серин > аргінін > гліцин > лейцин > феенілаланін > тирозин > треонін > валін > цистин > гістидин > ГАМК > ізолейцин > метіонін;

- жито посівне: глутамінова кислота > пролін > аспарагінова кислота > лейцин > аланін > лізин> аргінін > гліцин > фенілаланін > серин > треонін > гістидин > тирозин > валін > ізолейцин > цистин > метіонін > ГАМК.

У траві жита посівного та ячменю звичайного вміст незамінних амінокислот був майже од- наковим і становив 1,258 мг/100 мг (28,87 \% від суми амінокислот) і 1,159 мг/100 мг (19,35 \% від суми амінокислот) відповідно.

За вмістом серед незамінних амінокислот у траві жита посівного та ячменю звичайного в більшій кількості накопичувалися: лейцин (0,311 мг/100 мг та 0,202 мг/100 мг відповідно), лізин $(0,267$ мг/100 мг та 0,299 мг/100 мг відповідно), френілаланін (0,201 мг/100 мг та 0,199 мг/100 мг відповідно), в меншій - валін (0,129 мг/100 мг та 0,150 мг/100 мг відповідно), ізолейцин (0,109 мг/100 мг та 0,098 мг/100 мг відповідно).

Серед незамінних амінокислот у мінорній кількості у траві ячменю звичайного і жита посівного містився метіонін (0,061 мг/100 мг та 0,053 мг/100 мг відповідно).

Вміст замінних амінокислот у траві жита посівного був майже у 2,5 раза більшим, ніж незамінних, і становив 3,101 мг/100 мг (71,13\% від суми амінокислот). У траві ячменю звичайного він був у 4 рази вищим та складав 4,829 мг/100 мг (80,65 \% від суми амінокислот).

Трава ячменю звичайного накопичувала домінуючу кількість аспарагінової кислоти 1,535 мг/100 мг (25,63 \% від суми амінокислот), а у траві жита посівного їх було майже в 3,5 раза менше - 0,463 мг/100 мг (10,63 \% від суми амінокислот). 
В обох видах за вмістом переважали глутамінова кислота і пролін - 0,973 мг/100 мг та 0,780 мг/100 мг і 0,780 мг/100 мг та 0,479 мг/100 мг, у значній кількості накопичувались аланін і гліцин - 0,306 мг/100 мг та 0,285 мг/100 мг і 0,223 мг/100 мг та 0,249 мг/100 мг у траві ячменю звичайного і жита посівного відповідно.

Серед ідентисрікованих амінокислот вміст ГАМК був найменшим у траві жита посівного $(0,039 \mathrm{Mr} / 100 \mathrm{Mr})$.

ВИСНОВКИ. 1. Уперше вивчено амінокислотний склад і кількісний вміст амінокислот у траві ячменю звичайного (сорт Шедевр) і жита посівного (сорт Хамарка).

2. У досліджуваній сировині встановлено вміст 18 амінокислот, 3 яких 7 належать до незамінних, 8 - до замінних, 3 - до напівзамінних. Серед ідентифрікованих амінокислот домінували аспарагінова і глутамінова кислоти та пролін, у значній кількості містилися лейцин, лізин і фенілаланін.

3. Одержані результати проведених досліджень можуть бути використані при розробці нових рослинних лікарських засобів на основі ячменю звичайного і жита посівного.

\section{СПИСОК ЛІТЕРАТУРИ}

1. Аминокислоты глазами химиков, фрармацевтов, биологов : в 2 т. / [А. О. Сыровая, Л. Г. Шаповал, В. А. Макаров и др.]. - Х. : Щедра садиба плюс, 2015. - 2. -268 c.

2. Іосипенко О. О. Вивчення амінокислотного складу листя кабачків / О. О. Іосипенко, В. С. Кисличенко, 3. І. Омельченко // Мед. та клініч. хімія. 2020. - 22, № 2 (84). - С. 72-80.

3. Лысиков Ю. А. Аминокислоты в питании человека / Ю. А. Лысиков // Эксперим. и клинич. гастроэнтерология. - 2012. - № 2. - С. 88-105.

4. Пінкевич В. О. Дослідження амінокислотного складу сировини матіоли дворогої (Matthiola bicornis (Sibth. \& Sm.) DC.) сорту Цариця ночі / B. О. Пінкевич, І. О. Журавель, Н. Є. Бурда // Мед. та клініч. хімія. 2020. -22 , № 3 (85). - C. 48-53.

5. Odia A. Therapeutic uses of amino acids / A. Odia, O. Z. Esezobor. - In book: Amino Acid - New Insights and Roles in Plant and Animal. Publisher: InTechEditors: Toshiki Asao and Md. Asaduzzaman, 2017. - P. 4-14.

6. Waheed E. J. Biological activities of amino acid derivatives and their complexes a review / E. J. Waheed, S. M. H. Obaid, A. A. S. Al-Hamdani // Research Journal of Pharmaceutical, Biological and Chemical Sciences. 2019. - 10 (2). - Р. 1624-1641.

7. Амінокислотний склад солодів злакових культур / Л. О. Безсмертна, Н. О. Ємельянова, Р. М. Мукоїд, А. М. Матиящук // Наукові здобутки молоді у

\section{REFERENCES}

1. Syrovaya, A.O., Shapoval, L.G., Makarov, V.A., Petyunina, V.N., \& Graboveckaya, E.R. (2015). Aminokisloty glazami khimikov, farmatsevtov, biologov: $v$ 2-h t. Tom 2 [Amino acids through the eyes of chemists, pharmacists, biologists: in 2 vol. Vol. 2]. Kharkiv: Shchedra sadyba plius [in Ukrainian]. вирішенні актуальних проблем виробництва та переробки сировини, стандартизації і безпеки продовольства : матеріали II Міжнар. наук.-практ. конор. молодих вчених, аспірантів і студентів. - К., 2012. 4. 1. - C. 320-321.

8. The study of macro- and microelement composition of rye and barley / G. S. Tartynska, Moeen F. Dababneh, Naeem Shalan [et al.] // Research Journal of Pharmaceutical, Biological and Chemical Sciences. - 2018. 10 (2). - P. 314-317.

9. Волочай В. І. Вивчення амінокислотного складу трави галінсоги дрібноквіткової та галінсоги війчастої / В. І. Волочай, В. М. Ковальов // Запорож. мед. журн. 2012. - № 3 (72). - С. 44-46.

10. Шиморова Ю. Е. Изучение аминокислотного состава пастернака посевного (Pastinaca sativa L.) / Ю. Е. Шиморова, В. С. Кисличенко, Л.Н.Горячая // Norwegian Journal of development of the International Science. - 2020. - No. 38. - P. 42-45.

11. Determination of free and bound amino acids in plant raw materials of Zea mays $L$. by the method of high-performance liquid chromatography / U. V. Karpiuk, V. S. Kyslychenko, I. S. Cholak, O. I. Yemelianova // Pharmacognosy Research. - 2020. - 12. - P. 143-148.

12. Study of amino acid composition and basic technological parameters of viburnum fruits harvested in Ukraine / O. P. Khvorost, B. S. Leontiiev, A. O. Yaroshenko, O. S. Shpychak // Journal of Global Pharma Technology. - 2020. - 12 (1). - P. 618-624. 
3. Lysikov, Yu.A. (2012). Aminokisloty v pitanii cheloveka [Amino acids in human nutrition]. Eksperimentalnaya i klinicheskaya gastroenterologiya - Experimental and Clinical Gastroenterology, (2), 88-105 [in Russian].

4. Pinkevych, V.O., Zhuravel, I. O., \& Burda, N.Ye. (2020). Doslidzhennia aminokyslotnoho skladu syrovyny matioly dvorohoi (Matthiola bicornis (Sibth. \& Sm.) DC.) sortu Tsarytsia nochi [Study of the amino acid composition of raw materials of Matthiola bicornis (Sibth. \& Sm.) DC. Variety Queen of the Night]. Medychna ta klinichna khimiia - Medical and Clinical Chemistry, 3, 48-53 [in Ukrainian].

5. Odia, A., \& Esezobor, O.Z. (2017). Therapeutic uses of amino acids. In book: Amino Acid - New Insights and Roles in Plant and Animal. Publisher: InTechEditors: Toshiki Asao and Md. Asaduzzaman

6. Waheed, E.J., Obaid, S.M.H., \& Al-Hamdani, A.A.S. (2019). Biological activities of amino acid derivatives and their complexes a review. Research Journal of Pharmaceutical, Biological and Chemical Sciences, 10 (2), 1624-1641.

7. Bezsmertna, L.O., Emelyanova, N.O., Mukoyid, R.M., \& Matiyaschuk, A.M. (2012). Aminokislotnyi sklad solodiv zlakovykh kultur [Amino acid composition of cereal malts]. Naukovi zdobutky molodi u vyrishenni aktualnykh problem vyrobnytstva ta pererobky syrovyny, standartizatsii i bezpeky prodovolstva: II Mizhnarodna naukovo-praktychna konferentsiia molodykh vchenykh, aspirantiv i studentiv - Scientific Achievements of Young People in Solving Current Problems of Production and Processing of Raw Materials, Standardization and Food
Safety: Materials II International Scientific-practical Conf. Young Scientists, Graduate Students, 1, 320-321 [in Ukrainian].

8. Tartynska, G.S., Dababneh, M.F., Shalan, N., Zhuravel, I O., Kyslychenko, V.S. \& Popyk, A.I. (2018). The study of macro- and microelement composition of rye and barley Research Journal of Pharmaceutical, Biological and Chemical Sciences, 10 (2), 314-317.

9. Volochai, V.I., \& Kovalov, V.M. (2012). Vyvchennia aminokyslotnoho skladu travy halinsohy dribnokvitkovoi ta halinsohy viichastoi [Study of amino acid composition of the herb Galinsoga parviflora and Galinsoga ciliata]. Zaporozhskiy meditsynskiy zhurnal - Zaporozhye Medical Journal, 3 (72), 44-46 [in Ukrainian].

10. Shimorova, Y.Ye., Kyslychenko, V.S., \& Horiacha, L.M. (2020). Izuchenie aminokislotnogo sostava pasternaka posevnogo (Pastinaca sativa L.) [Amino acids composition study of parsnip (Pastinaca sativa L.)]. Norwegian Journal of Development of the International Science, 38, 42-45 [in Russian].

11. Karpiuk, U.V., Kyslychenko, V.S., Cholak, I.S., \& Yemelianova, O.I. (2020). Determination of free and bound amino acids in plant raw materials of Zea mays L. by the method of high-performance liquid chromatography. Pharmacognosy Research, 12, 143-148.

12. Khvorost, O.P., Leontiiev, B.S., Yaroshenko, A.O., \& Shpychak, O.S. (2020). Study of amino acid composition and basic technological parameters of viburnum fruits harvested in Ukraine. Journal of Global Pharma Technology, 12 (1), 618-624.

НАЦИОНАЛЬНЫЙ ФАРМАЦЕВТИЧЕСКИЙ УНИВЕРСИТЕТ ${ }^{1}$, ХАРЬКОВ ВИННИЦКИЙ НАЦИОНАЛЬНЫЙ МЕДИЦИНСКИЙ УНИВЕРСИТЕТ ИМЕНИ Н. И. ПИРОГОВА ИНСТИТУТ МИКРОБИОЛОГИИ И ИММУНОЛОГИИ ИМЕНИ И. И. МЕЧНИКОВА ${ }^{3}$, ХАРЬКОВ

\section{ИССЛЕДОВАНИЕ АМИНОКИСЛОТНОГО СОСТАВА ТРАВЫ ЯЧМЕНЯ ОБЫКНОВЕННОГО И РЖИ ПОСЕВНОЙ}

\section{Резюме}

Вступление. Аминокислоты имеют многовекторную фрармакологическую активность, поэтому актуальными являются поиск новых источников аминокислот и исследование их состава в лекарственных растениях.

Цель исследования - изучить качественный состав аминокислот, определить их содержание в траве ячменя обыкновенного и ржи посевной.

Методы исследования. Идентификацию и определение количественного содержания аминокислот проводили методом ионообменной жидкостно-колоночной хроматографии.

Результаты и обсуждение. В исследуемом сырье качественный состав и количественное содержание доминирующих аминокислот были почти идентичными. Общее содержание аминокислот в траве ячменя обыкновенного составило 5,988 мг/100 мг, в траве ржи посевной - 4,359 мг/100 мг. В траве ячменя обыкновенного среди заменимых аминокислот в значительном количестве накапливались аспарагиновая и глутаминовая кислоты и пролин (25,63 \%, 16,25 \%, 12,91 \% от суммы аминокислот соответственно), среди незаменимых - лизин (5,00 \% om суммы аминокислот). В траве ржи посевной по содержанию преобладали заменимые аминокислоты: глутаминовая кислота, пролин, аспарагиновая кислота (17,88 \%, 10,99 \%, 10,63 \% от суммы аминокислот соответствен- 
но), среди незаменимых - лейцин, лизин, френилаланин (7,14 \%, 6,13 \%, 4,61 \% от суммы аминокислот соответственно). Среди незаменимых аминокислот в минорном количестве в траве ржи посевной и ячменя обыкновенного содержался метионин $(1,40$ и 0,88 \% от суммы аминокислот соответственно).

Выводы. Впервые изучено качественный состав и определено количественное содержание аминокислот в траве ячменя обыкновенного и ржи посевной. Установлено содержание 18 аминокислот, из которых 7 относятся к незаменимым, 8 - к заменимым, 3 - к полузаменимым. Среди идентифицированных аминокислот доминировали аспарагиновая и глутаминовая кислоты, пролин, в значительном количестве содержались лейцин, лизин и френилаланин. Полученные результаты проведенных исследований могут быть использованы при разработке новых растительных лекарственных средств на основе ячменя обыкновенного и ржи посевной.

КЛЮЧЕВЫЕ СЛОВА: ячмень обыкновенныЙ; рожь посевная; аминокислоты; ионообменная жидкостно-колоночная хроматография.

G. S. Tartynska ${ }^{1}$, I. O. Zhuravel ${ }^{1}$, V. S. Kyslychenko', V. V. Hutsol ${ }^{2}$, A. V. Martynov ${ }^{3}$ NATIONAL UNIVERSITY OF PHARMACY ${ }^{1}$, KHARKIV M. PYROHOV VINNYTSIA NATIONAL MEDICAL UNIVERSITY², VINNYTSIA INSTITUTE OF MICROBIOLOGY AND IMMUNOLOGY NAMED AFTER I. MECHNIKOV ${ }^{3}$ KHARKIV

\section{STUDY OF THE AMINO ACID COMPOSITION OF THE HERB BARLEY AND RYE}

\section{Summary}

Introduction. Amino acids have multi-vector pharmacological activity, so the search for new sources of amino acids and the study of their composition in medicinal plants is relevant.

The aim of the study - to learn the high-quality composition of amino acids and determine their content in the herb of the barley and rye.

Research Methods. The identification and determination of the quantitative content of amino acids was carried out by the method of ion exchange fluid-column chromatography.

Results and Discussion. In the studied raw materials, the qualitative composition and quantitative content of the dominant amino acids were almost identical. The total content of amino acids in the herb of the bunch of ordinary was $5.988 \mathrm{mg} / 100 \mathrm{mg}$, rye $-4.359 \mathrm{mg} / 100 \mathrm{mg}$. In the grass, the bunch of ordinary among replaceable amino acids in significant quantities were accumulated: aspartic and glutamic acids and proline (25.63\%, $16.25 \%$ and $12.91 \%$ of the amount of amino acids, respectively), among the essential lysine (5.00\% of the amount amino acids). In the herb of rye content prevailed replaceable amino acids: glutamic acid, proline, asparagic acid (17.88 \%, 10.99\%, $10.63 \%$ of the amount of amino acids, respectively), essential - leucine, lysine, phenylalanine $(7.14 \%, 6.13 \%, 4.61 \%$ of the amount of amino acids, respectively). Among the essential amino acids in the herb of the barley and rye in minor quantities methionine were $(1.40 \%$ and $0.88 \%$ of the amino acid amount, respectively).

Conclusions. For the first time, a qualitative composition was studied and the quantitative content of amino acids in the herb of the barley and rye was determined. The content of 18 amino acids was established, of which 7 essential, 8 - replaceable and 3 - semi-essential. Among the identified amino acids, aspartic and glutamic acids were dominated, proline, leucine, lysine and phenylalanine were contained in significant quantities. The results of the research carried out can be used in the development of new plant medicines based on rye and barley.

KEY WORDS: barley; rye; amino acids; ion exchange liquid-column chromatography.

Отримано 12.03.21

Адреса для листування: Г. С. Тартинська, Національний фрармацевтичний університет, вул. Пушкінська, 53, Харків, 61002, Україна, e-mail: annatartynskaya1984@gmail.com. 